\title{
The Study on the Hearing Status of Adult in Their 20s according to the Body Mass Index Value
}

\author{
Mi Sook Lee ${ }^{1}$, Yong Gyu Seo ${ }^{2}$, Yeon Jin Lee ${ }^{3}$, Da Hae Jeong ${ }^{4}$, Mi Ni Jo ${ }^{5}$, Joo Hyung Kim ${ }^{6}$, Seung Wan Lee ${ }^{7}$ \\ 'Jeeum Auditory Rehabilitation Center, Daegu, Korea \\ ${ }^{2}$ Department of Speech-Language Pathology \& Audiology, Kaya University, Gimhae, Korea \\ ${ }^{3} \mathrm{O}$ 's Hearing Aids, Seoul, Korea \\ ${ }^{4}$ Asianstar, Seoul, Korea \\ ${ }^{5}$ Soree Ear Clinic, Seoul, Korea \\ ${ }^{6}$ Starkeykorea, Seoul, Korea \\ ${ }^{7}$ Department of Speech Pathology \& Audiology Graduate School, Chuncheon, Korea
}

\author{
체질량지수(BMI)에 따른 20대 성인의 청력 상태에 대한 연구 \\ 이미숙 ${ }^{1} \cdot$ 서용규 $^{2} \cdot$ 이연진 ${ }^{3} \cdot$ 정다혜 $^{4} \cdot$ 조민이 $^{5} \cdot$ 김주형 $^{6} \cdot$ 이승완 ${ }^{7}$

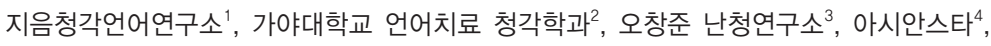 \\ 소리귀클리닉 ${ }^{5}$, 스타키코리아 ${ }^{6}$, 한림대학교 일반대학원 언어병리청각학과 ${ }^{7}$
}

\begin{abstract}
Purpose: The relationship between weight and hearing loss is unclear. But childhood obesity, defined as body mass index (BMI) $\geq 95 \%$, is a significant health problem associated with a variety of disorders, and in adults it has been found to be a risk factor for hearing loss. Thus in this study, analyzed the relationship between hearing loss and BMI in a 20s young adults. Methods: A total of 49 participants, including 27 females and 20 males aged 21-25 participated in this study. Subjects were divided into three groups according to BMI (underweight, normal, overweight). In all subjects, pure-tone and speech audiometry, acoustic immittance and otoacoustic emission [OAE; spontaneous otoacoustic emission (SOAE), transient evoked otoacoustic emission (TEOAE), distortion product otoacoustic emission (DPOAE)], auditory brainstem response (ABR) were evaluated. Results: The mean of hearing threshold in underweight group were significantly higher than normal group. Regarding the hearing threshold, the low frequency pure tone average threshold was significantly higher in underweight and overweight group. The incidences of SOAEs were $66.7 \%$ in normal group, $37.4 \%$ in underweight group and $11.1 \%$ in overweight group. Between BMI and OAE overweight group had significantly lower TEOAE amplitude. Amplitude of DPOAEs differed significantly among normal, underweight and overweigh BMl group at frequency of 4,000 Hz. Conclusion: We demonstrate for the first time that underweight and overweight in adult in their 20s is associated with higher hearing thresholds in low-frequency. And parameters of OAE, such as amplitude of TEOAE, DPOAE at $4,000 \mathrm{~Hz}$ was considered as good indicators for monitoring cochlear function of underweight and overweight BMl group.
\end{abstract}

Key Words: Body mass index, Overweight, Underweight, Hearing status, Otoacoustic emissions.

Received: September 6, 2017 / Revised: October 4, 2017 / Accepted: October 12, 2017

Correspondence: Mi Sook Lee, Jeeum Auditory Rehabilitation Center, 292-2 Daemyeong-ro, Nam-gu, Daegu 42449, Korea Tel: +82-53-471-8011 / Fax: +82-53-471-8013 / E-mail: zangmisook@hanmail.net

\section{INTRODUCTION}

비만이란 라틴어 obestias에서 유래한 것으로 어원은 '먹어치 웠다(eaten away), '걸신들린 듯 먹었다(devoured)'의 'obesus'에 서 유래된 것으로 섭취한 에너지량에 비해 소모된 에너지량이 적어 잉여 에너지가 발생하게 되고, 이 상태가 오래 계속되어 나타난 영양장애로 볼 수 있다. 비만은 성인병을 유발시키는 촉
진제가 될 뿐 아니라 심장병, 간질환, 당뇨병, 고혈압, 동맥경화 증을 15 40\% 증가시킨다. 또한 체중이 뼈와 관절에 부담을 주 게 되어 골격 이상을 초래할 수 있다. 궁극적으로 비만으로 인 한 질병은 공적 건강보험의 재정 악화와 의료비 부담 증가에 부 딪히게 되어 국가의 사회경제적 비용 부담 증가로 이어질 수 있 다. 세계보건기구(World Health Organization, WHO)에 따르 면 비만으로 인해 한 해 동안 전 세계적으로 발생하는 직접적 
인 사회적 부담은 2조 달러로, 전 세계 Gross Domestic Product 의 $2.8 \%$ 에 이른다고 하였다. 소득, 교육, 생활 여건의 향상은, 건강과 수명 증가에 기여해 왔지만 신체활동 감소, 에너지 섭취 증가, 잘못된 식습관 등은 비만 인구를 급속히 증가시키고 있는 추세이다. Ezzati \& Danaei(2014)는 186개국 18세 이상 성인 1,920 만 명의 자료를 분석한 결과 남성 $10.8 \%$ 와 여성 $14.9 \%$ 가 비만으로 조사됐으며, 전체 성인 비만율은 $12.9 \%$ 로 2014년 전 세계 인구를 기준으로 6 억 4,100만 명이 비만으로 조사됐다고 보고하였다. 따라서 이런 추세가 이어지면 2025년에는 성인 남 성의 $18 \%$, 여성의 $21 \%$ 가 비만이 될 것이라고 경고하였는데 이 는 남녀 성인 5 명 중 1 명꼴로 비만이 되는 셈이다. 국제 비만 대 책본부(International Obesity Task Force, 2010)에 의하면 전 세계 비만 인구는 2014년 현재 약 6억 4,000만 명으로 추계됐 는데, 이는 1975년 대비 6배 이상 증가한 수치로 비만의 사회적 문제를 제기하였다.

비만은 신체적, 정신적, 심리적 및 사회적 건강 전반에 걸쳐 영향을 미치는데 비만한 사람은 비만하지 않은 사람에 비하여, 제2형 당뇨병, 고지혈증, 인슐린 저항성, 대사증후군, 담낭 질환, 관상동맥 질환, 고혈압 등 만성질환에 잘 걸리며, 각종 암과 관 절 질환의 발병률이 높은 것으로 알려져 있다. 비만은 관상동 맥 질환의 위험을 $50 \%$ 높일 뿐 아니라, 남녀 모두에서, 모든 종 류의 심혈관계 질환에 의한 사망률과 관상동맥 질환에 의한 사 망률을 모두 50\% 높인다(Vorona et al., 2005). WHO 산하 국 제 암 연구소(International Agency for Research on Cancer, 2014)에서 비만과 대장/직장암, 폐경 후 유방암, 자궁내막암, 신 장암, 식도선암의 연관성을 보고하고 있으며, 2007년 신규 암 환자 중 남자의 4\%(약 3만 4,000명) 그리고 여자의 7\%(약 5만 500 명)는 비만에 의한 것으로 보고하고 있다. 국내의 경우 과체 중에 의한 암 발생 기여 위험도는 $1.84 \%$ (남자, $2.2 \%$; 여자 $1.5 \%$ ) 로 추계되었다(Park et al., 2016).

특히 기대수명의 연장으로 노인 인구는 지속적으로 증가 추 세인데 우리나라의 경우 2014년 현재 전체 인구에서 65세 이상 인구가 차지하는 비율은 $12.7 \%, 2030$ 년에는 $24.3 \%$ 로 노인 인구 수는 현재의 2배가 될 것으로 예상했다(Statistics Korea, 2015). 이들에서 비만 및 과체중으로 인한 여러 가지 만성질환의 이환 율 증가는 신체적 장애도를 증가시키는데(Guralnik, 1999) 기초 적 및 도구적 일상생활 수행 능력의 기능 제한으로 청력손실을 꼽을 수 있다(Hwang et al., 2009). 즉, 청력저하는 자연적 노령 화 과정에서 흔히 일어나는 현상이지만 과체중의 결합은 일상 생활 수행 능력을 더 침해받게 하고 그로 인한 사회적 보조 및 가족의 부담이 더 커질 수밖에 없다는 것이다. 아동-청소년 비 만 또한 지난 20 30년 사이 급속히 증가하고 있으며, 현재 전 세 계적으로 학령기 아동의 약 $10 \%$ 가 비만 또는 과체중으로 추정
되고 있다. 미국과 유럽에서 실시한 2001 2002 학령기 아동 건 강행태조사에서 $18.3 \%$ 가 과체중이고 $6.8 \%$ 가 비만이며, 많은 유 럽 국가의 경우 4.7 19.2\%가 과체중이고 5.1\%가 비만으로 나타났 다(Janssen et al., 2004). 우리나라도 아동 및 청소년 비만이 성인 비만보다 급속히 증가하는 추세로 남학생 비율이 $14.2 \%$ 로 여학 생 7.3\%보다 높았다(Statistics Korea, 2015). Lalwani et al.(2013) 은 12 세에서 19 세 사이 청소년 500 명의 조사 자료를 분석한 결 과, 비만 청소년의 경우 내유모 세포의 문제로 인하여, 편측성의 감각 신경성 난청이 발생하게 되는데 특히, 저주파 음역대(2,000 $\mathrm{Hz}$ 이하)에서 난청 발생률이 $15 \%$ 이상으로 나타나고 Burniat et al.(2002)은 10세의 과체중 또는 비만 아동에서 미도의 양이 청력손실을 보고하였다. 이렇듯 아동·청소년 비만이 주목받는 이유는 아동·청소년기 비만이 성인 비만으로 이어질 확률이 64 79\%에 이르고(Kurian et al., 2015; Whitaker et al., 1997) 이들에서는 대사이상의 소견을 보여 심혈관 질환 위험인자의 유 병률이 높고 심혈관 위험인자와 청력손실 간의 유의한 관련성을 보고하고 있어 건강 위험인자가 성인기로 이행하게 되면 개개인 의 질환은 물론 사회적으로 심각한 문제가 될 수 있기 때문이다.

청력기관의 기능은 혈액 운반, 신경학적 영향 등 종합적인 작 용으로 복잡하게 조절되고 있음에 따라 고지질증, 흡연 등과 청 력손실과의 관련성에 대한 연구가 많이 행해졌으며(Fransen et al., 2008; Hwang et al., 2013; Lalwani et al., 2013; Siegelaub et al., 1974; Valckx et al., 2012) 그 원인으로 귀의 혈액순환에 장애를 일으켜 영구적인 청력손실을 야기한다고 주장하였다. Bainbridge et al.(2011)은 비만이 청력손실에 영향을 미칠 수 있다고 보고 소음이나 이독성 약물, 흡연 등 청력장애에 영향을 미치는 요인을 보정한 상태에서 체질량지수가 높을수록 저주파 수와 고주파수 전 영역에서 청력장애의 위험을 증가시켜(Curhan et al., 2013) 청력손실은 흡연량과 체질량지수(body mass index, $\mathrm{BMI}$ 와 비례했다고 규정하였다. Sharon et al.(2013)은 여성 6만 8,000명에 대해 1989 2009년까지 20년간 BMI와 청력손실과의 관계를 추적조사한 결과 체질량지수가 30 39의 비만인 경우 체 질량지수 25 미만인 경우보다 청력 손상을 경험한 경우가 17 $22 \%$ 정도 더 높게 나타난다고 보고한 이후 BMI와 청력손실 간 의 관계를 입증하고자 하는 연구가 많이 이루어지고 있다. 우리 나라의 경우 Kim et al.(2016)은 경도 이상의 난청 비율이 과체 중 그룹에서 $21.8 \%$, 비만인 그룹에서 $21.2 \%$ 고도비만 그룹에 서 $24.1 \%$ 로 나타났고 과체중 그룹에서 1.312 배 높다고 하였다.

이렇듯 비만이 청력저하의 위험인자라면 청력 상태에 대한 면 밀한 연구는 청력저하 예방에 도움을 줄 수 있을 것이다. 그러 나 대부분 단지 순음청력검사를 통해 청력 상태를 보고한 연구 가 대부분이다. 따라서 본 연구는 신체적으로 건강한 20 대 대 학생들을 대상으로 정상체중, 과체중 그리고 저체중 그룹으로 
분류하여 순음청력검사(pure tone audiometer)를 비롯한 어음 청력검사(speech test), 뇌간유발반응검사(auditory brainstem response, $\mathrm{ABR}$ )를 통해 이들의 청력 상태를 알아보고자 하였 다. 또한, 순음청력검사로는 찾을 수 없지만 와우 기능의 민감한 변화를 추적할 수 있는 이음향방사검사(otoacoustic emission, $\mathrm{OAE}$ )를 실시해 와우 기능에 의미 있는 변화가 있는지 알아보 고자 하였다.

\section{MATERIALS AND METHODS}

\section{연구 대상}

연구 대상은 설문지를 통해 과거 이과적 질환의 병력과 흡연 을 보고하지 않은 고막 운동성 계측도상 정상적인 A type을 보 이는 19 24세(평균 $20.75 \pm 1.43$ 세) 대학생(남 20명, 여 27명)을 대상으로 하였다. 신장은 본인이 직접 기록하도록 하였고, 체중 은 동일한 체중계로 측정하였다. 체중과 신장으로부터 체질량지 수(BMI, $\mathrm{kg} / \mathrm{m}^{2}$ )를 계산한 후 체중의 상태를 평가하는 가장 보편 적 기준의 하나인 아시아 태평양의 비만기준법을 사용하여 저체 중(underweight, BMI $<18.5 \mathrm{~kg} / \mathrm{m}^{2}$ ) 그룹, 정상체중(normal weight, $18.5 \mathrm{~kg} / \mathrm{m}^{2} \leq \mathrm{BMI}<23.0 \mathrm{~kg} / \mathrm{m}^{2}$ ), 과체중 (overweight, $\left.23.0 \mathrm{~kg} / \mathrm{m}^{2} \leq \mathrm{BMI}<25.0 \mathrm{~kg} / \mathrm{m}^{2}\right)$ 총 세 그룹으로 나누었다. 본 연구에 참여한 남녀 대학생들은 연구방법과 실험절차에 대 한 설명을 듣고 연구참여 동의서에 서명한 후 실험에 임하였다. 연구 대상에 대한 정보는 Table 1과 같다.

\section{검사 장비}

이음향방사검사(OAE)는 ILO92 (Otodynamics Ltd.) 분석기 를 사용하여 측정하였다. 순음청력검사는 GSI-10 (GrasonStadler Co., Eden Prairie, MN, USA) 청력검사기를 이용해 실시 하였고 임피던스 검사는 GSI33 (Grason-Stadler Co.) 이미턴스 분석기(immitance analyser)를 이용해 측정하였다. 뇌간유발반 응검사는 GSI MASTER (Grason-Stadler Co.)를 사용하였다.

\section{검사 진행}

순음청력검사는 $35 \mathrm{dBA}$ 방음실에서 GSI-61 Audiometer (Grason-Stadler Co.)를 이용하여 250, 500, 1,000, 2,000, 4,000, $8,000 \mathrm{~Hz}$ 의 주파수를 양 귀에서 검사하였으며 평균 순음기도 청력역치를 3 분법 $(500+1,000+2,000 \mathrm{~Hz} / 3)$ 으로 측정하였다. 또한 $250,500,1,000 \mathrm{~Hz}$ 주파수 청력을 평균한 값을 저주파수 영역 평균 청력(low frequency pure tone averages, PTA-low) 으로, $2,000,4,000,8,000 \mathrm{~Hz}$ 주파수 청력을 평균한 값을 고주 파수 영역 평균 청력(high frequency pure tone averages, PTAhigh)으로 나누어 분석하였다. 뇌간유발반응검사에 사용된 자 극은 $0.2 \mathrm{~ms}$ 와 $80 \mathrm{~dB} \mathrm{nHL}$ 의 click으로 $30 \mathrm{~Hz}$ 에서 $3,000 \mathrm{~Hz}$ 의 대역통과필터(band-pass filter)가 사용되었고, 전체 2,000 sweep 자극의 지속 시간은 $200 \mathrm{sec}$ 로 희박상(rarefaction polarity) 조 건에서 검사하였다. 이때 $10 \mathrm{~dB}$ 간격의 수정 상승법을 이용하여 역치를 측정하였다. 이음향방사검사는 일과성 유발이음향방사 (transient evoked otoacoustic emission, TEOAE), 자발이음향 방사(spontaneous otoacoustic emission, SOAE), 변조이음향 방사(distortion product otoacoustic emission, DPOAE)는 $\mathrm{DPOAE}$ audiogram (DP-gram)을 측정하였다. SOAE는 평균 $75.4 \mathrm{~dB}$ peSPL ( $\mathrm{SD}=2.5 \mathrm{~dB}$ SPL)의 강도로 계산하였으며, 자극 지속음을 가진 클릭 신호는 $12.3 \mathrm{~Hz}$ 의 frequency resolusion을 가진 fast fourier transform으로 분석하였다. TEOAE는 검사 측 귀의 음향 자극(ipsilateral stimulus)은 평균 $78.6 \pm 1.2 \mathrm{~dB}$ SPL의 비선형 클릭음(click)으로 음의 지속 시간은 $80 \mu \mathrm{s}$, 자극 빈도는 초당 50회, 평균 가산은 260회로 설정하였다. DPOAE는 평균 가산을 최대 500 회로 하였고 DPOAE의 진폭(amplitude) 은 소음 기준선(noise floor)보다 $5 \mathrm{~dB} \mathrm{SPL}$ ( $3 \times$ standard deviation of noise floor) 높을 때 자동으로 측정은 중단되게 설정하 였다. 모든 피검자를 방음실 내 침대에 눕게 한 후 편안한 상태 를 유지하게 하였으며, 검사 중에는 말을 하지 않고 최대한 움 직이지 않도록 주의한 후 검사를 진행하였다.

자료의 분석은 체질량지수에 따라 세 그룹의 각 주파수별 기

Table 1. The average of the subjects classification by the BMI standard $(n=47)$

\begin{tabular}{|c|c|c|c|c|}
\hline & Age (years) & Height $(\mathrm{cm})$ & Weight (kg) & BMI \\
\hline \multicolumn{5}{|c|}{ Normal group $(\mathrm{n}=17)$} \\
\hline Male & $22.13 \pm 4.0$ & $174.23 \pm 6.2$ & $68.93 \pm 7.8$ & $20.46 \pm 1.03$ \\
\hline Female & $20.93 \pm 2.3$ & $160.71 \pm 5.4$ & $52.90 \pm 6.9$ & \\
\hline \multicolumn{5}{|c|}{ Underweight group $(\mathrm{n}=15)$} \\
\hline Male & $22.24 \pm 5.3$ & $172.06 \pm 5.3$ & $54.28 \pm 4.7$ & $17.45 \pm 0.54$ \\
\hline Female & $21.02 \pm 1.8$ & $163.63 \pm 7.3$ & $46.64 \pm 3.9$ & \\
\hline \multicolumn{5}{|c|}{ Overweight group $(\mathrm{n}=15)$} \\
\hline Male & $21.08 \pm 2.3$ & $173.66 \pm 5.5$ & $82.30 \pm 7.3$ & $25.78 \pm 2.95$ \\
\hline Female & $20.21 \pm 1.9$ & $161.49 \pm 8.7$ & $62.76 \pm 8.1$ & \\
\hline
\end{tabular}

BMI: body mass index 
도순음 청력역치와 저주파수 영역 평균 청력, 고주파수 영역 평 균 청력역치를 독립표준-t 검정을 이용하여 분석하였다. $\mathrm{SOAE}, \mathrm{TEOAE}$ 의 발현 비율 및 강도는 백분율로 나타냈으며, 주파수별 변조이음향방사의 진폭은 독립표준-t 검정으로 SPSS 18.0 프로그램(SPSS Inc., Chicago, IL, USA)에서 유의 수준 0.05 이하에서 분석하였다.

\section{RESULTS}

\section{순음청력검사의 결과}

세 그룹에서의 주파수별 순음청력검사 역치의 평균값과 표 준편차를 나타낸 것으로 주파수가 커질수록 역치 값은 작아지

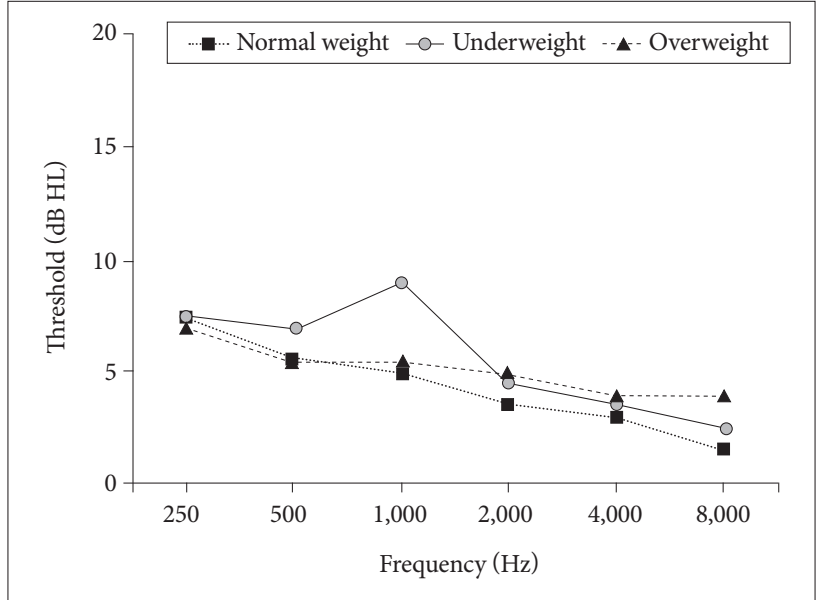

Figure 1. Mean threshold per frequency in pure tone audiogram.
는 양상을 보였으며(Figure 1, Table 2), 250 8,000 Hz의 모든 주파수대역에서 기도순음 청력역치 값은 평균 $10 \mathrm{~dB}$ 이내에 있 었으며 3분법으로 계산한 평균 역치는 통계적으로 유의하게 과 체중 그룹에서 낮고 저체중 그룹에서 높은 역치를 나타냈다. 정 상 체중 그룹과 비교해 저체중 그룹과 과체중 그룹의 경우 250, $500 \mathrm{~Hz}$ 주파수에서는 통계적으로 유의한 차이가 없었으나 1,000 , $2,000,4,000,8,000 \mathrm{~Hz}$ 에서는 유의하게 높았다 $(p<0.05)$.

저주파수 $(250,500,1,000 \mathrm{~Hz})$ 와 고주파수 $(2,000,4,000$, $8,000 \mathrm{~Hz}$ )로 나누어 세 그룹의 역치를 비교한 결과 저주파수 영 역과 고주파수 영역 평균 청력에서 정상체중, 과체중, 저체중 그 룹 순으로 역치가 높았다. 또한 모든 그룹에서 저주파수 영역의 역치가 고주파수 영역의 역치에 비해 높았다 $(p<0.05)$ (Table 3).

세 그룹의 주파수별 좌우 역치 비교 결과 과체중 그룹의 경 우 3분법으로 계산한 오른쪽 귀의 역치는 $8.97 \pm 7.63 \mathrm{~dB} \mathrm{HL}$, 왼쪽 귀는 $5.83 \pm 4.55 \mathrm{~dB} \mathrm{HL}$ 로 오른쪽 귀의 역치가 유의하게 높게 나타났으나 $(p<0.05)$, 정상체중 그룹과 저체중 그룹에서 는 유의한 차이가 없었다(Figure 2).

\section{이음향방사(OAE) 검사 결과}

\section{일과성음유발이음향방사(TEOAE)}

$\mathrm{TEOAE}$ 는 재현율(wave reproducibility)과 반응 강도(response)로 분석하였으며 TEOAE의 반응 강도(amplitude of response)는 $5 \mathrm{~dB}$, 재현성(reproducibility)은 $70 \%$ 이상을 양성 으로 재현성과 반응 강도 모두에서 양성이면 pass로 판정하였

Table 2. Mean puretone threshold by frequency in 3 group

\begin{tabular}{ccccc}
\hline Frequency $(\mathrm{Hz})$ & Normal group $($ mean $\pm \mathrm{SD})$ & Underweight group $(\mathrm{mean} \pm \mathrm{SD})$ & Overweight group $(\mathrm{mean} \pm \mathrm{SD})$ & $p$-value \\
\hline 250 & $7.5 \pm 5.2$ & $7.5 \pm 3.5$ & $7.0 \pm 5.0$ & $5.5 \pm 4.3$ \\
500 & $5.5 \pm 5.8$ & $7.0 \pm 2.8$ & $5.5 \pm 2.1$ & 0.320 \\
1,000 & $5.0 \pm 4.4$ & $9.0 \pm 1.4$ & $5.0 \pm 1.4$ & 0.423 \\
2,000 & $3.5 \pm 4.8$ & $4.5 \pm 1.0$ & $4.0 \pm 3.5$ & $0.020^{*}$ \\
4,000 & $3.0 \pm 3.0$ & $3.5 \pm 1.4$ & $4.0 \pm 3.2$ & $0.000^{* *}$ \\
8,000 & $1.5 \pm 4.9$ & $2.5 \pm 0.7$ & $0.032^{*}$ & $0.003^{*}$ \\
\hline$p$-value & $0.035^{*}$ & $0.028^{*}$ & \\
\hline
\end{tabular}

${ }^{*} p<0.05,{ }^{* *} p<0.01$. SD: standard deviation

Table 3. Mean threshold and SD for low-and high-frequency in 3 group

\begin{tabular}{|c|c|c|c|c|c|}
\hline \multirow{2}{*}{ Frequency $(\mathrm{Hz})$} & \multirow{2}{*}{ Mean } & \multicolumn{3}{|c|}{ Puretone threshold } & \multirow{2}{*}{$p$-value } \\
\hline & & Normal group & Underweight group & Overweight group & \\
\hline \multirow[t]{2}{*}{ PTA-low } & Mean & 6.50 & 7.25 & 6.75 & $0.052^{*}$ \\
\hline & SD & 4.03 & 4.35 & 5.06 & \\
\hline \multirow[t]{2}{*}{ PTA-high } & Mean & 3.87 & 4.75 & 4.63 & $0.010^{*}$ \\
\hline & SD & 2.73 & 2.95 & 1.79 & \\
\hline \multicolumn{2}{|c|}{$p$-value } & $0.000^{* *}$ & $0.001^{*}$ & $0.000^{* *}$ & \\
\hline
\end{tabular}

${ }^{*} p<0.05,{ }^{* *} p<0.01$. PTA-low : low frequency pure tone average, PTA-high : high frequency pure tone average, SD: standard deviation 
다. 세 그룹 전체 인원 47명 94귀를 대상으로 검사한 결과 7귀에 서 TEOAE가 나타나지 않아 총 87귀(92.6\%)에서 발현율을 보 였으며 각 그룹의 발현 비율은 Table 4와 같다.

세 그룹의 재현율은 정상체중 그룹은 $96.6 \pm 3.8 \%$, 저체중 그 룹 $95.8 \pm 3.4 \%$, 과체중 그룹 $92.2 \pm 2.4 \%$ 로 과체중 그룹에서 낮게 나타났다 $(p<0.05)$ (Table 5). 또한, 세 그룹 모두 좌측에 비해 우측의 재현율 및 강도가 높았으나 통계적인 유의성은 없 었다.

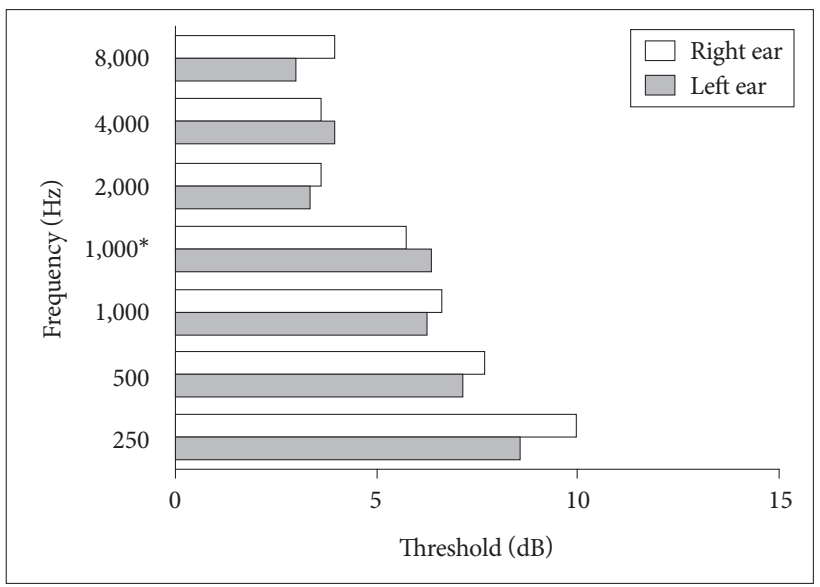

Figure 2. Air-conduction threshold level by side in group with BMI $23.0 \mathrm{~kg} / \mathrm{m}^{2} \leq \mathrm{BMI}<25.0 \mathrm{~kg} / \mathrm{m}^{2}$. *retest. BMl: body mass index.

\section{자발이음향방사(SOAE)}

$\mathrm{SOAE}$ 는 자발이음향방사가 한 개라도 나타나면 peak 개수와 주파수 강도로 분석하였는데 정상체중 그룹의 경우 총 17 명 중 10 명에서 발현되어 $66.7 \%$ 의 발현율을 보였으며 저체중 그룹은 $37.4 \%$, 과체중 그룹은 $11.1 \%$ 로 과체중 그룹에서 발현율이 낮았 다(Table 6). 발현 주파수 범위는 $500 ~ 6,000 \mathrm{~Hz}$ 사이에서 측정 되었으며 가장 많이 관찰된 주파수 영역은 1,000 2,000 Hz 부 근이었다. 여자 피검자의 발현 비율은 $62.5 \%$ 로 남자 피검자 $27.6 \%$ 에 비해 높았으며 오른쪽 귀에서 발현 비율이 더 높았다.

\section{변조이음향방사(DPOAE)}

$\mathrm{DPOAE}$ 는 제시되는 순음의 강도를 일정하게 하고 주파수를 변화시키는 DP-gram으로 분석하였으며 주파수에 따른 평균 진폭은 Table 7과 같다.

$\mathrm{DPOAE}$ 는 각 $\mathrm{GM}$ 에서 2f1-f2 강도를 분석해 본 결과, 7 22 $\mathrm{dB} / \mathrm{SPL}$ 내의 반응 진폭을 보였으며 세 그룹을 비교한 결과 정

Table 4. Positive rate of response amplitude of TEOAE in 3 group

\begin{tabular}{lccc}
\hline & Positive (\%) & Negative (\%) & Total \\
\hline Normal group & $17(100.0)$ & $0(0.0)$ & 17 \\
Underweight group & $12(80.0)$ & $3(20.0)$ & 15 \\
Overweight group & $11(73.3)$ & $4(26.7)$ & 15 \\
\hline
\end{tabular}

Positive rate: wave reproducibility of TEOAE $>70 \%$, amplitude response $>5 \mathrm{~dB}$. TEOAE: transient evoked otoacoustic emission

Table 5. Amplitude of response of transient evoked otoacoustic emission in 3 group

\begin{tabular}{lcccc}
\hline & Normal group & Underweight group & Overweight group & $p$-value \\
\hline Amplitude of response (\%) & $96.6 \pm 3.8$ & $95.8 \pm 3.4$ & $92.2 \pm 2.4$ & $0.035^{*}$ \\
Response (dB) & $13.6 \pm 6.6$ & $13.3 \pm 7.2$ & $12.2 \pm 4.4$ & $0.038^{*}$ \\
\hline
\end{tabular}
${ }^{*} p<0.05$

Table 6. Positive rate of response amplitude and presence of spontaneous otoacoustic emission in 3 group

\begin{tabular}{lcccc}
\hline & Presence $(\%)$ & Peak $(\mathrm{N})$ & Frequency $(\mathrm{Hz})$ & Amplitude $(\mathrm{dB}$ SPL) \\
\hline Normal group & 66.7 & $3.1 \pm 0.8$ & $1,068 \pm 0.9$ & $7.2 \pm 5.7$ \\
Underweight group & 37.4 & $2.6 \pm 1.1$ & $1,362 \pm 1.2$ & $8.1 \pm 6.9$ \\
Overweight group & 11.1 & $3.7 \pm 1.9$ & $1,434 \pm 1.4$ & $8.6 \pm 7.1$ \\
\hline
\end{tabular}

Table 7. Mean amplitude of distortion product otoacoustic emission in 3 group

\begin{tabular}{|c|c|c|c|c|c|c|}
\hline \multirow{2}{*}{ Frequency $(\mathrm{Hz})$. } & \multicolumn{2}{|c|}{ Normal group } & \multicolumn{2}{|c|}{ Underweight group } & \multicolumn{2}{|c|}{ Overweight group } \\
\hline & Rt (dB/SPL) & $\mathrm{Lt}(\mathrm{dB} / \mathrm{SPL})$ & Rt (dB/SPL) & $\mathrm{Lt}(\mathrm{dB} / \mathrm{SPL})$ & $\mathrm{Rt}(\mathrm{dB} / \mathrm{SPL})$ & $\mathrm{Lt}(\mathrm{dB} / \mathrm{SPL})$ \\
\hline 500 & $12.0 \pm 3.8$ & $12.5 \pm 6.5$ & $7.4 \pm 5.1$ & $10.6 \pm 8.4$ & $11.8 \pm 3.3$ & $10.3 \pm 1.6$ \\
\hline 1,000 & $19.2 \pm 8.7$ & $20.2 \pm 7.5$ & $20.7 \pm 5.8$ & $22.5 \pm 9.8$ & $19.5 \pm 3.0$ & $18.8 \pm 2.6$ \\
\hline 2,000 & $20.0 \pm 9.1$ & $21.1 \pm 9.9$ & $22.0 \pm 9.9$ & $22.9 \pm 8.8$ & $18.4 \pm 5.9$ & $21.8 \pm 7.5$ \\
\hline 3,000 & $18.1 \pm 6.1$ & $19.2 \pm 9.3$ & $20.0 \pm 8.8$ & $20.3 \pm 9.2$ & $17.4 \pm 5.2$ & $19.4 \pm 5.3$ \\
\hline 4,000 & $20.7 \pm 9.3$ & $21.6 \pm 8.2$ & $19.3 \pm 7.5$ & $20.8 \pm 7.0$ & $17.9 \pm 4.9$ & $21.3 \pm 4.9$ \\
\hline 6,000 & $19.2 \pm 6.3$ & $20.6 \pm 5.1$ & $18.4 \pm 10.2$ & $20.0 \pm 9.2$ & $16.5 \pm 8.6$ & $20.3 \pm 6.0$ \\
\hline 8,000 & $17.6 \pm 4.4$ & $19.2 \pm 3.1$ & $17.7 \pm 8.2$ & $19.5 \pm 12.1$ & $18.7 \pm 8.0$ & $21.9 \pm 6.8$ \\
\hline Mean \pm SD & \multicolumn{2}{|c|}{$18.6 \pm 6.4$} & \multicolumn{2}{|c|}{$18.7 \pm 8.5$} & \multicolumn{2}{|c|}{$18.1 \pm 5.3$} \\
\hline
\end{tabular}


상체중 그룹의 경우 $18.6 \pm 6.4 \mathrm{~dB} / \mathrm{SPL}$, 저체중 그룹은 $18.7 \pm$ $8.5 \mathrm{~dB} / \mathrm{SPL}$, 과체중 그룹은 $18.1 \pm 5.3 \mathrm{~dB} / \mathrm{SPL}$ 로 과체중 그룹 의 진폭이 낮았으나 유의한 차이는 보이지 않았다. 주파수별로 분석해 보았을 때 세 그룹 모두 $1,000 \mathrm{~Hz}$ 이상의 주파수 대역에 비해 $500 \mathrm{~Hz}$ 에서 반응 진폭이 낮았으며, 그 값은 정상체중 그룹 은 $12.3 \pm 3.8 \mathrm{~dB} / \mathrm{SPL}$, 저체중 그룹 $9.01 \pm 6.7 \mathrm{~dB} / \mathrm{SPL}$, 과체중 그룹 $11.1 \pm 2.5 \mathrm{~dB} / \mathrm{SPL}$ 로 저체중 그룹에서 유의하게 낮은 반 응 진폭을 보였다 $(p<0.05)$. 순음청력검사의 고주파수(PTAhigh)의 주파수 대역에서 저체중, 과체중 그룹의 역치가 유의하 게 높아 이들 주파수 대역과 $4,000 \mathrm{~Hz}$ 변조이음향방사의 주파 수 대역을 비교하였다. 그 결과 저체중 및 과체중 그룹에서 정상 체중 그룹에 비해 진폭이 유의하게 낮았다 $(p<0.05)$ (Table 8).

\section{뇌간유발반응(ABR)검사 결과}

세 그룹의 평균역치의 경우 정상체중 그룹 $42.3 \mathrm{~dB} \mathrm{nHL}$, 저체중 그룹 $43.8 \mathrm{~dB} \mathrm{nHL}$, 과체중 그룹 $45.2 \mathrm{~dB} \mathrm{nHL}$ 로 과체중 그룹에서 높게 나타났으나 통계적인 유의성은 없었다 $(p>0.05)$ (Table 9).

\section{DISCUSSIONS}

순음청력검사의 결과 모든 그룹의 대상자들은 250 8,000 $\mathrm{Hz}$ 전대역의 주파수에서 평균 $10 \mathrm{~dB} \mathrm{HL}$ 이내의 역치를 보였 다. 이들의 청력도 유형상 주파수가 커질수록 역치는 낮았으며 평균역치는 정상체중 그룹은 $4.25 \pm 2.78 \mathrm{~dB} \mathrm{HL}$, 저체중 그룹의 경우 $6.75 \pm 3.84 \mathrm{~dB} \mathrm{HL}$, 과체중 그룹의 경우 $5.73 \pm 3.0 \mathrm{~dB} \mathrm{HL}$ 로 저체중 그룹에서 유의하게 역치가 높았다. 또한 각 그룹별 남 녀 간 평균역치는 유의한 차이는 보이지 않았다. 특히 과체중 그 룹의 경우 오른쪽 귀의 역치는 $8.97 \pm 7.63 \mathrm{~dB} \mathrm{HL}$, 왼쪽 귀는 $5.83 \pm 4.55 \mathrm{~dB}$ HL로 오른쪽 귀의 역치가 유의하게 높게 나타 났으나 $(p<0.05)$, 정상체중 그룹과 저체중 그룹에서는 유의한 차이가 없었다. 이에 대해 18 40세 이상의 여성 40명을 대상으

Table 8. Mean amplitude of distortion product otoacoustic emission in $4,000 \mathrm{~Hz}$

\begin{tabular}{lccc}
\hline & $\begin{array}{c}\text { Mean DP amplitude } \\
(\mathrm{dB} / \mathrm{SPL})\end{array}$ & Number & $p$-value \\
\hline Normal group & $21.2 \pm 8.0$ & 17 & \\
Underweight group & $20.1 \pm 13.1$ & 15 & $0.016^{*}$ \\
Overweight group & $19.2 \pm 10.8$ & 15 & \\
\hline$* p<0.05$ & & &
\end{tabular}

로 비만과 청력손실의 관계를 연구한 Üçler et al.(2016)에 의하 면 왼쪽 귀는 의미 있는 반응이 보이지 않았으나 오른쪽 귀는 정 상체중의 경우 $16.03 \pm 4.72 \mathrm{~dB} \mathrm{HL}$, 비만 여성은 $16.15 \pm 2.72$ $\mathrm{dB} \mathrm{HL}$ 로 비만 여성에서 특히 고주파수에서 유의하게 역치가 높 았다고 보고하였다. 본 연구의 결과 정상체중 그룹에 비해 과체 중 그룹에서 우측위의 역치가 높게 나타나 위의 연구를 지지하 나 오히려 고주파수에서 유의하게 역치가 낮았는데 Üçler et al.(2016) 연구의 평균 역치값보다 $10 \mathrm{~dB} \mathrm{HL}$ 정도 낮았다. 이에 대해 나이에 따른 청력손실(age-related hearing loss) 가설을 통해 설명할 수 있다. 보통 청력의 감소는 30대부터 시작되지만 회화 영역에 청력감소가 생겨 실제로 잘 안 들리는 것을 느낄 수 있는 것은 40대 이후부터이며 60대 정도면 더욱 현저해진다 (Kim et al., 2016). 본 연구는 $\geq 15 \mathrm{~dB}$ HL의 정상청력인 20 25 세 범위의 피검자만을 대상으로 연구했고 위의 저자는 18세부 터 40대까지 연령 범위가 조금 더 다양하고 30대, 40대 대상자 들이 상당히 많이 포함되어 있기 때문이라고 추측할 수 있다. 남녀별 청력 상태를 연구한 Hwang et al.(2009)은 성별에 따른 청력도 유형에서 유의한 변화를 보이지 않았다고 하였으며 본 연구에서도 성별에 따른 유의한 결과는 보이지 않았다. 주파수별 특성은 250 1,000 Hz를 저주파수로 $2,000 \mathrm{~Hz}$ 이상을 고주파수 로 나누어 분석한 평균청력역치는 세 그룹 모두 고주파수에 비 해 저주파수에서 그리고 저체중 그룹에서 유의하게 높았으며 평균청력 차이는 1 2 $\mathrm{dB}$ HL 정도였다. 비만과 관련하여 청력 상태를 연구한 대부분은 고주파수 청력손실을 보고하였고( $\mathrm{Da}$ browski et al., 2013; Hwang et al., 2009; Üçler et al., 2016), 이들은 청각계의 노화는 $2,000 \mathrm{~Hz}$ 이상의 고주파수에서 나타 난다는 특징과 관련하여 설명하였다. Bainbridge et al.(2011)은 소음이나 이독성 약물, 흡연 등 청력장애에 영향을 미치는 요인 을 보정한 후에도 저주파수와 고주파수 영역 모두에서 청력장애 의 위험을 증가시킨다고 하였으나 Kim et al.(1998)은 비만에 의 해 중간주파수와 고주파수 영역의 청력손실을 보고하였다. 그 러나 본 연구와 비슷한 연령대의 12 19세 청소년 1,488명을 대 상으로 청력검사를 실시한 Lalwani et al.(2013)은 비만 청소년 의 경우 $2,000 \mathrm{~Hz}$ 이하 저주파수 난청률이 $15.16 \%$ 로 정상체중 $7.89 \%$ 보다 2배가량 높다고 하였는데 본 연구에서도 과체중 그 룹에서 저주파수 영역의 역치가 고주파수 영역의 역치에 비해 높았다.

Kim et al.(2016)은 한국인 6만 1,052명을 대상으로 몸무게와

Table 9. Mean threshold auditory brainstem response in 3 group

\begin{tabular}{lccccc}
\hline & Site & Normal group & Underweight group & Overweight group & $p$-value \\
\hline Threshold (dBnHL) & Rt & $42.2 \pm 7.5$ & $42.5 \pm 11.9$ & $48.3 \pm 10.4$ & 0.068 \\
& Lt & $42.5 \pm 6.4$ & $45.0 \pm 14.7$ & $42.0 \pm 17.3$ & 0.129 \\
\hline
\end{tabular}

${ }^{*} p<0.05$. Rt: right, Lt: left 
청력손실과의 관계를 연구했는데 저체중 그룹의 $24.9 \%$ 에서 경 도의 난청을 보였으며 정상 그룹과 비교 시 저체중은 1.28 배 청 력손실 발생률이 높다고 하였다. 이들의 연구에서 주목할 것은 저체중 그룹에서의 청력손실에 대한 결과이다. 본 연구결과 순 음청력역치의 경우 다른 두 그룹에 비해 저체중 그룹에서 역치 가 약간 높았으며 이음향방사검사에서 자발이음향방사의 출현 율은 과체중 그룹보다 높았으나 정상체중 그룹에 비해 유의하 게 낮았다. 유발이음향방사와 변조이음향방사 진폭의 경우 정상 체중 그룹에 비해 낮았다. 특히 $500 \mathrm{~Hz}$ 변조이음향방사의 진폭 은 세 그룹 중 가장 낮은 값을 보였다. 미국의 경우 비만(BMI > 30)뿐만 아니라 저체중 $(\mathrm{BMI}<18.5)$ 도 정상체중에 비해 사망 률을 증가시키는 것으로 보고되나(Flegal et al., 2007) 이들에 서 청력 실태에 관한 연구는 거의 없는 형편이다. 신체 이미지 왜곡으로 인한 무리한 다이어트, 영양 섭취의 중요성에 대한 간 과 등 여러 가지 요인으로 저체중 여성이 증가하고 있는 현실에 서 과체중 및 비만인뿐만 아니라 저체중 대상자들에 대한 관심 이 필요하다. 본 연구에서 오른쪽 귀의 역치가 왼쪽 귀에 비해 높게 나타났는데 과체중 그룹에서 통계적으로 유의하였다. 이 에 대해 Kannan \& Lipscomb(1974)는 일반 남자 인구 집단에 서의 청력역치에 대한 역학적 연구에서 $4,000 \mathrm{~Hz}$ 주파수대에서 평균 청력역치는 좌측 귀가 더 높다고 보고하였다. 이러한 결과 는 좌측 귀가 소음에 대한 감수성이 높기 때문이라는 의견이나 좌우측 귀의 청력역치의 비대칭에 영향을 미치는 요인으로는 이질환, 사격 및 편중된 소음 노출, 청력기계의 안정성 등을 들 수 있고 이러한 경우를 제외한 일상적인 소음 노출에 의한 원인 은 정확히 밝혀지지 않았다. 본 연구에 참여한 대상자들의 경우 전화 통화 등 주로 사용하는 귀로 오른쪽 귀를 꼽았고(82.97\%) 이에 따라 오른쪽 귀의 역치가 높은 이유를 추정해 볼 수 있다. 즉, 오른쪽 귀는 수리적 능력에 관여하는 좌뇌의 지배를 받으 며, 말이나 숫자 등이 잘 들린다. 따라서 실제 대화를 할 때 오른 쪽 귀를 더 사용하는 이유가 된다. 이에 따라 오른쪽 귀를 더 많 이 사용하게 되고 이로 인해 역치 상승이 나타난 것으로 사료되 나 이는 추후 더 많은 대상자를 통한 연구가 필요할 것이다.

이음향방사검사의 결과, 특히 비만은 혈관을 수축시켜 고혈 압을 유발하므로 달팽이관에 공급되는 혈액의 흐름을 손상시 키기 때문에 청력손실을 일으키는 요인으로 지목되고 있다 (Sharon et al., 2013). 즉, 내이의 혈류가 어떤 질환이나 장애로 인해 혈관이 수축되거나 막히면 유모세포로의 산소 공급이 감 소함으로써 청력손실이 일어날 수 있는 것이다. 따라서 순음청 력검사로 확진되지 않는 경우 난청의 감별진단(Avan \& Bonfils, 1993) 및 유모세포와 관련하여 와우 기능의 민감한 변화를 추 적하는 데 이음향방사를 이용할 수 있다는 연구에 근거해 SOAE, $\mathrm{TEOAE}$ 그리고 $\mathrm{DPOAE}$ 를 시행하였다. $\mathrm{SOAE}$ 의 출현 비율은
정상체중 그룹, 저체중 그룹 과체중 그룹 순으로 비율이 높게 나 타났다. 그러나 주파수 및 SOAE의 peak의 개수, 진폭의 크기는 유의한 차이가 보이지 않았다. 그러나 여자 피검자의 발현 비율 은 $62.5 \%$ 로 남자 피검자 $27.6 \%$ 에 비해 높았으며 오른쪽 귀에서 출현 비율이 더 높았다. SOAE는 정상청력일지라도 최소 $13 \%$ 에 서 최고 44\%의 출현율(Probst, 1990)을 우리나라의 경우 Chang et al.(1997)은 정상청력군에서 $22.4 \%, 25 \mathrm{~dB}$ 이상의 감각신경성 난청군에서는 전혀 발현되지 않아 임상의 지표로 난청에서 사 용될 수 있음을 강조하였다. 본 연구의 저체중 및 과체중이나 정상청력인 피검자들임에도 출현율이 정상체중에 비해 유의하 게 낮은 결과를 도출하였으나 비정상적인 와우 상태로 결론 내 기에는 무리가 따른다. 그 이유로는 자발이음향방사 출현율은 정상청력일지라도 연구자마다 다르다는 점, 그리고 높은 진폭 의 자발이음향방사는 와우의 병적 상태를 의미하나 본 저체중 및 과체중 그룹 대상자들은 진폭 높이 및 출현 주파수는 정상 인 그룹과 유의미한 차이를 보이지 않았기 때문이다. 일과성음 유발이음향반사의 경우 $30 \sim 35 \mathrm{~dB} \mathrm{HL}$ 이상의 감각신경성 난청 인은 나타나지 않지만 정상청각 기능의 경우 $100 \%$ 발현된다고 보고하고 있다(Kemp et al., 1986). 그러나 본 연구의 경우 세 그 룹 모든 피검자의 경우 정상청력임에도 불구하고 정상체중 그 룹은 17 명의 피검자 모두 나타나 $100 \%$ 출현율을 보였으나 저체 중 및 과체중 그룹의 경우 약 $75 \%$ 정도 출현율을 보였다. 특히 저체중 그룹과 과체중 그룹에서 청력역치가 높은 저주파수 대 역의 경우 일과성음유발이음향반사의 진폭 또한 높지 않았는데 이는 정상적인 주파수에서는 광대역 주파수 방사 범위(broad frequency emission spectra)가 높게 나타나므로 청력손실이 있 는 주파수에서 진폭이 감소한(Robinette, 1986) 연구를 지지해주 고 있다. Dabrowski et al.(2013)은 BMI와 관련하여 콜레스테롤 이 높은 그룹에서 TEOAE가 나타나지 않았고 콜레스테롤과 $\mathrm{TEOAE}$ 진폭은 양의 상관관계(positive correlation)를 보인다 고 하였다. 이는 BMI가 증가할수록 혈액성상 수치에 바람직하 지 않은 영향을 끼칠 수 있고 결국 유모세포로 유입되는 혈류를 방해하기 때문이다. 이는 TEOAE 진폭이 높을수록 좋은 out hair cell 기능을 의미한다면 현재 임상에서 사용하고 있는 소음 및 약물중독 등 청력장애에 영향을 미치는 요인 추적 외에 초기 유모세포의 손상에 직접적으로 유해하게 작용하여 청력손실로 유도할지도 모를 비만도에 따른 유해성을 신속하고 간편하게 관찰 및 추적할 수 있을 수 있다. DPOAE는 와우의 외유모세 포의 상태를 가장 잘 볼 수 있으며 미로성(cochlear)과 후미로성 (retrocochlear)을 감별하는 데 사용하고 있다(Lonsbury-Martin et al., 1991). 특히 소음에 노출된 근로자의 변조이음향방사 의 감소는 청력손실의 잠재성을 가질 수 있고, 소음에 의해 와 우의 미세한 기능부전에서 보일 수 있는 변조이음향방사의 손 
실은 순음청력검사상에서 나타나는 소음성 난청의 경향을 보임 에 따라(Lee et al., 2005) 제시되는 순음의 강도를 일정하게 하 고 주파수를 변화시키는 DP-gram으로 500 8,000 Hz의 주파 수 대역을 측정하였다. 그 결과 모든 그룹에서 발현되어 정상청 력인에서 DPOAE는 90\% 이상 발현된다(Lonsbury-Martin et al., 1991; Musiek \& Baran, 1997)는 연구를 뒷받침했고 남성보 다는 여성에서 우측 귀의 진폭이 높았으나 통계적인 유의성은 없었다. 세 그룹 모두 $2,000 \mathrm{~Hz}$ 이상의 주파수대역에 비해 500 $\mathrm{Hz}$ 에서 반응 진폭이 낮았다 $(p<0.05)$, 이는 소음은 변조이음 향방사에 영향을 줄 수 있는데 피검자 자체 내에서 발생하는 생 리적인 소음뿐만 아니라 배경소음에 영향을 받을 수 있어 저주 파수 진폭 반응이 낮게 측정된 것으로 볼 수 있다. 또한 Musiek et al.(1997)은 변조이음향방사는 선별검사에서 정상청력과 비 정상청력을 정확히 확인하는 데 있어서 고주파수에서는 높은 정확성을 보이지만 저주파수에서는 청력 상태의 예측이 떨어질 수 있다고 하여 본 연구결과를 설명할 수 있다. 각 그룹에서 변 조이음향방사의 평균 진폭값 정상체중 그룹은 $12.0 \pm 3.8 \mathrm{~dB} /$ $\mathrm{SPL}$, 과체중 그룹은 $11.8 \pm 3.3 \mathrm{~dB} / \mathrm{SPL}$, 저체중 그룹은 $7.4 \pm$ $5.1 \mathrm{~dB} / \mathrm{SPL}$ 로 나타나 저체중 그룹에서 유의하게 낮은 $(p<0.05)$ 반응 진폭을 보였다. 특히 Oh \& Lee(2003)가 $70 \mathrm{~dB} \mathrm{SPL} \mathrm{(f1)의}$ 자극음에 의한 변조이음향방사 진폭만을 이용해 $4,000 \mathrm{~Hz}$ 에 서 난청의 정도를 감별할 수 있는 변조이음향방사 진폭의 감별 기준점을 제시했으므로 이를 근거로 순음청력검사의 주파수대 역 4,000 Hz에서 변조이음향방사의 진폭을 비교하였다. 그 결과 정상체중 그룹의 경우 $21.2 \pm 8.7 \mathrm{~dB} / \mathrm{SPL}$, 저체중 그룹 $20.1 \pm$ $7.23 \mathrm{~dB} / \mathrm{SPL}$, 과체중 그룹은 $19.6 \pm 5.36 \mathrm{~dB} / \mathrm{SPL}$ 을 보여 진폭 반응이 유의하게 낮게 나타났다. $4,000 \mathrm{~Hz}$ 에서 유의한 결과를 보인 것은 이들이 정상의 청력 상태를 보였으므로 순음청력검 사로는 검출되지 않지만 이음향방사에 민감하게 반응한 것인지 와우의 상태를 반영하는가에 대한 의문은 있으나, 그럴지라도 미세한 변화에도 민감한 변조이음향방사의 특성을 보인 것이라 고 할 수 있다. 따라서 추후 더 많은 피검자를 대상으로 한 연구 가 이루어진다면 비만에 의한 와우의 이상 유무를 조기에 예측 하는 것이 가능하다고 판단된다.

본 연구를 통해 과체중 대상자들의 청력손실에 관한 의미 있 는 결과는 도출하지 못했으나 이음향방사검사를 통해 청력역치는 정상 범위일지라도 저체중 및 과체중인 20대 성인에서 TEOAE 와 $\mathrm{DPOAE}$ 의 진폭이 낮았다는 결과는 도출하였다. 일반적으 로 이음향방사는 진폭의 변화를 통해 와우 기능을 객관적으로 평가한다고 할 때 본 연구결과를 활용해 향후 더 많은 대상자 를 통한 연구가 필요하리라 생각된다. 특히 20대 대학생들의 경 우 식사가 불규칙하고 잦은 음주 및 흡연율을 보이면서도 마른 체형에 대한 지나친 관심과 체중 조절은 건강 문제를 야기할
수밖에 없다. 따라서 이들에 대한 전반적인 청력 실태를 파악하 기 위한 과정이 선행될 필요가 있다. 또한 건강에 대한 인식 개 선 및 청력보존 프로그램 등 건강한 노년을 맞이하는 프로그램 의 개발이 필요할 것이다. 본 연구의 경우 적은 수의 인원을 대 상으로 하였으므로 추후 연령에 따라 더 많은 인원을 대상으 로 저체중 및 과체중(비만)이 청력저하에 미치는 영향에 대한 전향적인 추적연구가 필요하다고 생각된다.

중심 단어 : 체질량지수·과체중·저체중·청력 상태· 이음향방사.

\section{REFERENCES}

Avan, P. \& Bonfils, P. (1993). Frequency specificity of human distortion product otoacoustic emissions. Audiology, 32(1), 12-26.

Bainbridge, K. E., Hoffman, H. J., \& Cowie, C. C. (2011). Risk factors for hearing impairment among U.S. adults with diabetes: National Health and Nutrition Examination Survey 1999-2004. Diabetes Care, 34(7), 1540-1545.

Burniat, W., Cole, T. J., Lissau, I., \& Poskitt, E. M. E. (2002). Child and Adolescent Obesity: Causes and Consequences, Prevention and Management. (pp. 3-27, 221-239). Cambridge: Cambridge University Press.

Chang, S. O., Jung, H. W., Jang, Y. J., Kim, C. D., Park, H. J., \& Kim, C. S. (1997). Spontaneous otoacoustic emissions in the subjects with tinnitus and/or sensorineural hearing loss. Korean Journal of Audiology, 1(1), 76-79.

Curhan, S. G., Eavey, R., Wang, M., \& Stampfer, G. C. (2013). Body mass index, waist circumference, physical activity, and risk of hearing loss in women. The American Journal of Medicine, 126(12), 1142.e1-8.

Dąbrowski, M., Mielnik-Niedzielska, G., \& Nowakowski, A. (2013). Impact of different modifiable factors on hearing function in type 1 and type 2 diabetic subjects. A preliminary study. Annals of Agricultural and Environmental Medicine, 20(4), 773-778.

Ezzati, M. \& Danaei, G.; Global Burden of Metabolic Risk Factors of Chronic Diseases Collaborating Group. (2014). High serum cholesterol: a missed risk factor for chronic kidney disease mortality--authors' reply. The Lancet. Diabetes and Endocrinology, 2(8), 614.

Flegal, K. M., Graubard, B., Williamson, D. F., \& Gail, M. H. (2007). Causespecific excess deaths associated with underweight, overweight, and obesity. JAMA, 298(17), 2028-2037.

Fransen, E., Topsakal, V., Hendrickx, J. J., Van Laer, L., Huyghe, J. R., Van Eyken, E., et al. (2008). Occupational noise, smoking, and a high body mass index are risk factors for age-related hearing impairment and moderate alcohol consumption is protective: a European populationbased multicenter study. Journal of the Association for Research in Otolaryngology, 9(3), 264-276; discussion 261-263.

Guralnik, J. M. (1999). The impact of vision and hearing impairments on health in old age. Journal of the American Geriatrics Society, 47(8), 10291031.

Hwang, J. H., Hsu, C. J., Yu, W. H., Liu, T. C., \& Yang, W. S. (2013). Diet-induced obesity exacerbates auditory degeneration via hypoxia, inflammation, and apoptosis signaling pathways in CD/1 mice. PLoS One, 8(4), e60730.

Hwang, J. H., Wu, C. C., Hsu, C. J., Liu, T. C., \& Yang, W. S. (2009). Association of central obesity with the severity and audiometric configurations of age-related hearing impairment. Obesity (Silver Spring, Md.), 17(9), 1796-1801.

International Agency for Research on cancer. Retrieved from http://www. iarc.fr [cited 2014, October 29].

International Obesity Task Force. (2010, August 24). STRATEGIC PLAN 
FOR IOTF Draft. World Obesity. Retrieved from https://www.worldobesity.org/iotfmediaarchive/.

Janssen, I., Katzmarzyk, P. T., Boyce, W. F., King, M. A., \& Pickett, W. (2004). Overweight and obesity in Canadian adolescents and their associations with dietary habits and physical activity patterns. The Journal of Adolescent Health, 35(5), 360-367.

Kannan, P. M. \& Lipscomb, D. M. (1974). Letter: Bilateral hearing asymmetry in a large population. The Journal of the Acoustical Society of America, 55(5), 1092-1094.

Kemp, D. T., Bray, P., Alexander, L., \& Brown, A. M. (1986). Acoustic emission cochleography--practical aspects. Scandinavian audiology. Supplementum, 25, 71-95.

Kim, J. S., Yeh, M. H., Chun, B. Y., Woo, K. H., Kang, Y. S., Kim, K. Y., et al. (1998). Effect of cigareet smoking on air-conduction hearing threshold level in adult men. Journal of Preventive Medicine and Public Health, 31(2), 285-292.

Kim, S. H., Won, Y. S., Kim, M. G., Baek, Y. J., Oh, I. H., \& Yeo, S. G. (2016). Relationship between obesity and hearing loss. Acta Oto-Laryngologica, 136(10), 1046-1050.

Kurian, R. A., Thomas, C. J., Mathew, A., \& Velusamy, S. (2015). The association of obesity and blood pressure in children studying in schools in a rural area. Journal of Medical Science and Clinical Research, 3(1), 3657-3663.

Lalwani, A. K., Katz, K., Liu, Y. H., Kim, S., \& Weitzman, M. (2013). Obesity is associated with sensorineural hearing loss in adolescents. The Laryngoscope, 123(12), 3178-3184.

Lee, J. S., Kim, B. G., Kim, Y. B., Park, I. S., \& Oh, S. Y. (2005). Comparison of hearing threshold levels and distortion product otoacoustic emissions by history of military service. Korean Journal of Audiology, 9(1), 56-64.

Lonsbury-Martin, B. L., Whitehead, M. L., \& Martin, G. K. (1991). Clinical applications of otoacoustic emissions. Journal of Speech, Language, and Hearing Research, 34, 964-981.

Musiek, F. E. \& Baran, J. A.(1997). Distortion product otoacoustic emissions: Hit and false-positive rates in normal-hearing and hearing-im- paired subjects. The American Journal of Otology, 18, 454-461.

Oh, S. Y. \& Lee, W. C. (2003). The predictive study for hearing loss using distortion product otoacoustic emission in mild noise-induced hearing loss. Korean Journal of Occupational and Environmental Medicine, 15(3), 290-298.

Park, S. W., Lee, D. W., Park, J. W., Ryoo, S. B., Shin, R., \& Jeong, S. Y. (2016). Impact of body mass index on overall survival after surgery for colorectal cancer. Korean Journal of Clinical Oncology, 12(2), 91-96.

Probst, R. (1990). Otoacoustic emissions: An overview. In Pfaltz, C. R. New Aspects of Cochlear Mechanics and Inner Ear Pathophysiology (pp. 1091). Basel: Karger.

Robinette, M. S. (1986). Clinical observation with transient evoked otoacoustic emissions with adults. Seminars in Hearing, 13, 23-36.

Siegelaub, A. B., Friedman, G. D., Adour, K., \& Seltzer, C. C. (1974). Hearing loss in adults: Relation to age, sex, exposure to loud noise, and cigarette smoking. Archives of Environmental Health, 29(2), 107-109.

Statistics Korea. (2015, April 20). The Population Censuses in Korea, 2015 (Complete Enumeration Survey). Statistics Korea. Retrieved from http://kostat. go.kr/portal/korea/kor_nw/2/9/1/index.board?bmode=read\&aSeq= 356061.

Üçler, R., Turan, M., Garça, F., Acar, İ., Atmaca, M., \& Çankaya, H. (2016). The association of obesity with hearing thresholds in women aged 1840 years. Endocrine, 52(1), 46-53.

Valckx, S. D., De Pauw, I., De Neubourg, D., Inion, I., Berth, M., Fransen, E., et al. (2012). BMI-related metabolic composition of the follicular fluid of women undergoing assisted reproductive treatment and the consequences for oocyte and embryo quality. Human reproduction (Oxford, England), 27(12), 3531-3539.

Vorona, R. D., Winn, M. P., Babineau, T. W., Eng, B. P., Feldman, H. R., \& Ware, J. C. (2005). Overweight and obese patients in a primary care population report less sleep than patients with a normal body mass index. Archives of Internal Medicine, 165(1), 25-30.

Whitaker, R. C., Wright, J. A., Pepe, M. S., Seidel, K. D., \& Dietz, W. H. (1997). Predicting obesity in young adulthood from childhood and parental obesity. The New England Journal of Medicine, 337(13), 869-873. 